\title{
PERFORMA BIBIT RUMPUT LAUT Gracilaria verrucosa HASIL KULTUR JARINGAN DENGAN BUDIDAYA METODE SEBAR (BROADCAST) DI TAMBAK KABUPATEN SINJAI
}

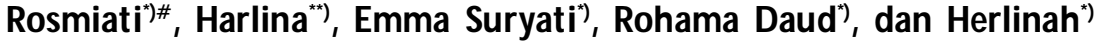 \\ *) Balai Riset Perikanan Budidaya Air Payau dan Penyuluhan Perikanan \\ Jl. Makmur Dg. Sitakka No. 129, Maros 90512, Sulawesi Selatan \\ *) Universitas Muslim Indonesia \\ JI. Urip Sumoharjo KM 4, Makassar, Sulawesi Selatan
}

(Naskah diterima: 10 Juni 2019; Revisi final: 30 Oktober 2019; Disetujui publikasi: 30 Oktober 2019)

\begin{abstract}
ABSTRAK
Rumput laut Gracilaria verrucosa asal Kabupaten Sinjai memiliki kualitas paling rendah di antara semua sentra produksi Gracilaria sp. di Sulawesi Selatan. Hal ini salah satunya dikarenakan oleh bibit yang buruk. Penyediaan benih rumput laut yang berkualitas dapat dilakukan salah satunya dengan penggunaan bibit hasil kultur jaringan. Perbanyakan bibit Gracilaria verucosa dapat dilakukan dengan menggunakan metode tali panjang long line maupun metode sebar (broadcast) di tambak. Tujuan penelitian ini untuk mengetahui respons pertumbuhan, kandungan agar, dan kekuatan gel (gel strength) dari bibit G. verucosa hasil kultur jaringan di tambak Kabupaten Sinjai. Metode penelitian ini adalah eksperimen dengan dua perlakuan dan tiga ulangan yaitu perlakuan A (bibit kultur jaringan) dan B (bibit lokal) dengan berat awal masing-masing $10 \mathrm{~kg}$. Pemeliharaan bibit dengan metode sebar dilakukan selama 30 hari. Hasil analisis ragam menunjukkan bahwa laju pertumbuhan harian (DGR), kandungan agar dan gel strength bibit kultur jaringan dan bibit lokal menunjukkan perbedaan yang nyata $(P<0,05)$. Secara kuantitas hasil produksi bibit hasil kultur jaringan memiliki pertumbuhan yang lebih tinggi daripada bibit lokal dengan berat akhir bibit 44,3 $\pm 4,16 \mathrm{~kg}$ hasil kultur jaringan dan 33,0 \pm 4,35 kg lokal dengan DGR 4,97\%bobot/hari (kultur jaringan) dan 3,90\%bobot/ hari (lokal). Secara kualitas bibit hasil kultur jaringan lebih baik dari bibit lokal, ditunjukkan dengan persentase kandungan agar bibit hasil kultur jaringan lebih tinggi daripada bibit lokal dengan rendemen agar 22,19 $\pm 2,45 \%$ (kultur jaringan) dan $16,50 \pm 0,96 \%$ (lokal), sementara gel strength sebesar $204,20 \pm 0,45 \mathrm{~g} / \mathrm{cm}^{2}$ (hasil kultur jaringan) dan 128,10 $\pm 1,55 \mathrm{~g} / \mathrm{cm}^{2}$ (bibit lokal).
\end{abstract}

KATA KUNCl: metode sebar; bibit; Gracilaria verucosa; Kabupaten Sinjai

ABSTRACT: Growth performance and quality of tissue-cultured seaweed seed Gracilaria verrucosa cultured using broadcast method in brackishwater Pond, Sinjai Regency. By: Rosmiati, Harlina, Emma Suryati, Rohama Daud, and Herlinah

Seaweed Gracilaria verrucosa from Sinjai Regency has thelowest quality among all Gracilaria sp. Production centers in South Sulawesi due to the low quality of the seed. The seed quality can beimproved using seed selection, followed by tissue-culture methods. Long-line and broadcast methods in brackishwater ponds are the efficient seaweed culture techniques to multiply the number of Gracilaria verrucosa seeds. This research was aimed to determine growth performance, gel content, and gel strength of seeds produced from tissue-culture and local seaweed farming. The experiment consisted of two treatments: treatment A (cells culture seed) and B (local seed) with the initial weight of 10 $\mathrm{kg}$, each has three replicates. Both seeds were stocked and reared in the ponds using the broadcast method for 30 days. The results of DGR, gel content and gel strength showed a significant difference between tissue-cultured and local seeds $(P<0.05)$. The tissue-cultured seed had better growth than the local seed with $4.97 \%$ mass/day for tissue-cultured seed and 3.90 mass/day for local seed. The tissue-culture seed also had better quality in agar content and gel strength. The agar content of tissue-cultured was $22.19 \pm 2.45 \%$ and the local was $16.50 \pm 0.96 \%$ The gel strength of tissueculture was $204.20 \pm 0.45 \mathrm{~g} / \mathrm{cm} 2$, and the local was $128.10 \pm 1.55 \mathrm{~g} / \mathrm{cm}^{2}$.

\section{KEYWORDS: Gracilaria verucosa; seed; broadcast method; Sinjai Regency}

\footnotetext{
\# Korespondensi: Balai Riset Perikanan Budidaya Air Payau dan

Penyuluhan Perikanan. Jl. Makmur Dg. Sitakka No. 129,

Maros 90512, Sulawesi Selatan, Indonesia.

Tel. + 6241137154

E-mail: emirosmiati@ yahoo.com
} 


\section{PENDAHULUAN}

Kabupaten Sinjai merupakan salah satu daerah potensial untuk pengembangan budidaya rumput laut di Sulawesi Selatan. Potensi tambak tersebar di tiga kecamatan yakni Sinjai Utara, Sinjai Timur, dan Tellu Limpoe. Kabupaten Sinjai terdiri atas 10 desa/ kelurahan yang terletak di daerah pesisir yang sangat memungkinkan untuk pengembangan budidaya rumput laut jenis Gracilaria sp. karena memiliki areal pertambakan seluas 615,43 ha (DKP Sinjai, 2014). Gracilaria verrucosa adalah salah satu jenis rumput laut yang dapat dibudidayakan di tambak. Di daerah Palopo harga rumput laut ini mencapai Rp5.000,00/kg kering pada musim tertentu, namun dapat berfluktuasi hingga Rp1.800,00-Rp3.200,00/kg kering ketika awal musim kemarau, serta anjloknya nilai rupiah (Amir, 2018). Namun demikian jenis rumput laut ini mempunyai potensi untuk meningkatkan kesejahteraan masyarakat pesisir. Menurut Trawanda et al. (2014), beberapa keunggulan budidaya rumput laut ini adalah (1) produk yang dihasilkan mempunyai kegunaan yang beragam, (2) tersedianya lahan budidaya yang cukup luas, dan (3) mudahnya teknologi budidaya yang diperlukan.

Budidaya rumput laut Gracilaria verucosa di Kabupaten Sinjai selama ini masih menggunakan metode sebar (broadcast) dari bibit yang berulang digunakan, yaitu dari rumput laut sisa panen periode sebelumnya yang disimpan untuk dijadikan bibit pada budidaya periode berikutnya. Berdasarkan laporan penyuluh bibit tersebut telah digunakan selama lebih dari 20 tahun. Padahal bibit yang digunakan berulang secara terus-menerus kuantitas produksi maupun kualitas agarnya akan menurun karena telah membawa bibit penyakit atau daya tahan terhadap penyakit telah berkurang (Parenrengi et al., 2011). Salah satu upaya yang telah dilaksanakan antara lain melalui seleksi untuk mendapatkan bibit yang relatif seragam, selanjutnya akan digunakan sebagai indukan untuk perbanyakan melalui teknik kultur jaringan untuk mendapatkan bibit rumput laut yang berkualitas.

Produksi bibit rumput laut $\mathrm{G}$. verrucosa hasil kultur jaringan di laboratorium Balai Riset Perikan Budidaya Air Payau dan Penyuluhan Perikanan (BRPBAP3) telah dilaksanakan menggunakan indukan yang diperoleh dari hasil seleksi yang sehat tidak terkontaminasi dengan penyakit, memiliki keunggulan tertentu seperti cepat tumbuh dan tahan terhadap penyakit, serta dapat diperbanyak secara aseptis. Performa bibit rumput laut hasil kultur jaringan yang dihasilkan telah diuji di tambak Kabupaten Sinjai dengan menggunakan metode rawai (long line method) (Rosmiati, 2017). Paper ini melaporkan performa bibit rumput laut hasil kultur jaringan menggunakan metode sebar (broadcast method) di tambak. Tujuan penelitian ini untuk mengetahui pertumbuhan dan kandungan agar bibit $G$. verucosa hasil kultur jaringan menggunakan metode sebar di tambak Kabupaten Sinjai.

\section{BAHAN DAN METODE}

\section{Lokasi Penelitian}

Penelitian ini dilaksanakan di pesisir Desa Lappa Kecamatan Sinjai Utara Kabupaten Sinjai. Sedangkan analisis kandungan agar dan kekuatan gel (gel strength) dilakukan di Laboratorium Bioteknologi, Balai Riset Perikanan Budidaya Air Payau dan Penyuluhan Perikanan Maros.

\section{Bahan Penelitian}

Bahan yang digunakan dalam penelitian ini berupa rumput laut jenis Gracilaria verucosa hasil kultur jaringan. Rumput laut yang digunakan sebagai bibit kultur jaringan dikumpulkan dari Kabupaten Sinjai. Thallus yang telah diseleksi dipotong-potong secara seragam dengan panjang $1 \mathrm{~cm}$. Eksplan tersebut kemudian dilakukan sterilisasi secara bertingkat di mulai dengan antibiotik $0,1 \%$ betadine $1 \%$ dan dibilas dengan air laut steril 25 ppt. Eksplan kemudian dipelihara selama delapan minggu di laboratorium dengan menggunakan media PES dalam stoples yang di-shaker dengan pencahayaan menggunakan lampu TL 1.500 lux pada suhu $25^{\circ} \mathrm{C}$. Aklimatisasi dilakukan di tambak Kabupaten Sinjai menggunakan hapa selama 60 hari dan dilanjutkan dengan perbanyakan benih selama 30 hari di tambak percobaan di lokasi yang sama dengan metode rawai (long line method). Perbanyakan bibit rumput laut lokal Kabupaten Sinjai juga dilakukan dengan metode yang sama.

\section{Metode Penelitian}

\section{Persiapan tambak}

Sebelum digunakan, petak tambak yang akan dijadikan lokasi budidaya dilakukan pengeringan petak tambak dengan cara dijemur sampai kering. Pembersihan saluran air dari kotoran, gulma, dan perbaikan pendangkalan. Pemberantasan hama dilakukan dengan aplikasi saponin $\pm 50 \mathrm{~kg} / \mathrm{ha}$. Pemasukan air ke dalam petak tambak dilakukan sampai kedalaman $60 \mathrm{~cm}$, dibiarkan tergenang selama 24 jam, kemudian dibilas dengan cara membuang total air rendaman saat surut sampai kering selama 1-2 hari. Pemupukan dasar tambak dilakukan dengan pupuk urea dan TSP dengan dosis $10 \mathrm{~kg} / \mathrm{ha}$ dan selanjutnya pengisian air dilakukan secara bertahap sampai mencapai $60 \mathrm{~cm}$ di atas pelataran tambak, dibiarkan selama dua minggu dan siap ditanami bibit. 


\section{Produksi benih rumput laut hasil kultur jaringan}

Kegiatan produksi benih dimulai dengan seleksi benih yang akan digunakan dari hasil perbanyakan benih menggunakan metode long line. Benih dipilih yang masih muda, ber-thalus banyak, elastis, bersih; serta memiliki pertumbuhan yang optimal sebanyak $10 \%$ dari populasi yang terbaik, kemudian dilakukan penimbangan bibit hasil kultur jaringan (A) dan bibit lokal Kabupaten Sinjai (B); masing-masing sebesar 10 $\mathrm{kg}$ per wadah. Benih baik hasil kultur jaringan maupun benih lokal, kemudian disebar di dalam hapa menggunakan waring hitam berukuran $4 \mathrm{~m} \times 4 \mathrm{~m}$ dengan ukuran mata jaring $\pm 3 \mathrm{~mm}$ yang pada empat tiang bambu. Masing-masing perlakuan dibuat ulangan sebanyak tiga kali. Pemeliharaan benih dilakukan selama satu siklus (30 hari) pemeliharaan. Pergantian air, pembersihan waring dari lumpur, dan penggantian wadah dilakukan pada hari ke-15 dari siklus pemeliharaan.

\section{Laju pertumbuhan harian}

Pengukuran pertumbuhan dan produksi bibit rumput laut dilakukan pada hari ke-15 dan akhir pemeliharaan dengan cara menimbang bibit pada awal, 15 dan 30 hari setelah pemeliharaan. Perhitungan laju petumbuhan harian (daily growth rate/DGR) menggunakan rumus Subandiyono \& Hastuti (2014), sebagai berikut:

$$
\operatorname{DGR}(\% \text { hari })=\frac{\operatorname{LnWt}-\operatorname{LnW0}}{\mathrm{T}} \times 100 \%
$$

di mana:

$\mathrm{Wt}=$ bo bot bibit rumput laut pada t hari $(\mathrm{g})$

Wo $=$ adalah bo bot awal bibit rumput laut $(\mathrm{g})$

$\mathrm{T}=$ adalah masa pemeliharaan (hari)

\section{Pengukuran Kandungan Agar}

Pengukuran kandungan agar dilakukan pada awal dan akhir penelitian dengan melakukan penimbangan sampel kering bibit rumput laut. Sebanyak $10 \mathrm{~g}$ sampel kering tersebut direndam dalam 0,25\%larutan kapo rit selama $3 \times 24$ jam pada suhu ruangan. Rumput laut kemudian dibilas dan direndam dengan air tawar selama tiga jam untuk selanjutnya direndam menggunakan $0,1 \%$ asam sulfat selama 15 menit. Setelah perendaman dengan asam sulfat, sampel direndam selama 15 menit dalam air tawar dilanjutkan dengan ekstraksi agar dengan cara dimasak menggunakan $500 \mathrm{~mL}$ akuades sampai sisa air menjadi sepertiga bagian. Agar yang dihasilkan disaring dan dituang ke dalam nampan untuk pengeringan menggunakan sinar matahari. Sampel yang telah kering ditimbang dan dilakukan pengukuran kandungan agar dengan menggunakan rumus yang dikemukakan oleh Anggadiredja et al. (2010) sebagai berikut:

Kandungan agar $\left(\%=\frac{\text { Bobot agar }(\mathrm{g})}{\text { Bobot sampel kering }(\mathrm{g})} \times 100 \%\right.$

\section{Pengukuran Kekuatan Gel (Gel Strength)}

Pengukuran kekuatan gel (gel strength) dilakukan dengan cara yang sama pada proses penentuan kandungan agar, namun dengan berat sampel yang lebih besar, yaitu $50 \mathrm{~g}$. Lembaran agar yang sudah kering dipotong-potong kemudian ditepungkan menggunakan blender. Sekitar 6,67 g tepung agar tersebut dipreparasi dengan membuat larutan agar menggunakan blender dengan penambahan $100 \mathrm{~mL}$ akuades. Agar-agar tepung kemudian dipreparasi dengan cara di-blender basah dengan menggunakan akuades sebanyak $100 \mathrm{~mL}$ untuk $6,67 \mathrm{~g}$ sampel (digunakan metode komposit sampel) dengan tiga ulangan dengan masing-masing ulangan yaitu $2,22 \mathrm{~g}$ untuk tiap kode, dihomogenkan dengan menggunakan stirrer di atas hot plate sampai suhunya mencapai $65^{\circ} \mathrm{C}$. Setelah penyimpanan selama 16 jam pada suhu $10^{\circ} \mathrm{C}$ selanjutnya diukur kekuatan gel mengunakan gel strength apparatus dengan pengamatan pada layar komputer.

Untuk menghitung kekuatan gel rumput laut digunakan rumus sebagai berikut:

$$
\text { Kekuatan gel }\left(\mathrm{g} / \mathrm{cm}^{2}\right)=\frac{\text { Nilai puncak tertinggi }}{\text { Luas bidang penekan }}
$$

$$
\begin{array}{ll}
\text { di mana: } & \\
\text { Diameter } & =1,27 \mathrm{~cm} \\
r & =0,63 \mathrm{~cm} \\
\delta & =3,14 \text { (luas bidang penekan }=1,26 \mathrm{~cm}^{2} \text { ) }
\end{array}
$$

\section{Kualitas Air}

Parameter kualitas air yang diukur secara in situ adalah salinitas, suhu, dan $\mathrm{pH}$. Sementara pengukuran kandungan fosfat, amoniak, dan nitrat dilakukan di laboratorium menggunakan alat spektrofotometer UV-VIS merk Shimadzu. Pengambilan contoh air dilakukan di tiga titik pengamatan di sekitar lokasi penelitian yaitu, di pintu air masuk, pintu air keluar, dan dalam tambak. Contoh air dimasukkan dalam botol sampel poliethylen yang mempunyai volume $500 \mathrm{~mL}$. Botol-botol sampel tersebut kemudian dimasukkan dalam sebuah cool box yang sudah berisi es batu dan dibawa ke laboratorium. Pengukuran kualitas air dilakukan pada awal dan setiap tujuh hari masa pemeliharaan. 


\section{Analisis Data}

Rancangan percobaan yang digunakan adalah rancangan acak lengkap dengan tiga kali ulangan. Data yang diperoleh dianalisis ragam dengan menggunakan uji One Way Anova dengan add ins Excel pada taraf kepercayaan 0,05.

\section{HASIL DAN BAHASAN}

\section{Produksi dan Laju Pertumbuhan Bibit}

Dari hasil pengamatan terhadap morfologi rumput laut terlihat bahwa rumput laut hasil kultur jaringan (A) memiliki percabangan yang lebih panjang dibandingkan bibit lokal (B) (Gambar 1).

Hasil pengamatan morfologi (Gambar 1) memperlihatkan perbedaan antara bibit hasil kultur jaringan dan lokal antara lain pada bentuk, ukuran, dan tekstur thallus yang lebih bersih dan panjang. Hal ini diduga karena pada kultur jaringan terjadi proses peremajaan bibit di laboratorium, di mana bibit yang digunakan pada kultur di laboratorium adalah bibit yang masih muda atau meristematik. Meskipun struktur sel kedua sumber benih tidak dilakukan analisis dalam ekperimen ini. Mulyaningrum et al. (2015) melaporkan bahwa susunan sel G. verrucosa hasil kultur jaringan memiliki sel medula yang tidak teratur, berbentuk lonjong, dan banyak terdapat ruang yang kosong antar sel. Selain itu, sel korteks hasil kultur jaringan juga memiliki susunan yang kurang rapat sehingga meskipun pada salinitas rendah bibit hasil kultur jaringan masih bisa hidup dengan baik karena proses transpor nutrien masih dapat berjalan dengan baik. Berat bibit rumput laut hasil kultur jaringan dan lokal selama 0,15 , dan 30 hari pemeliharaan ditunjukkan dalam Tabel 1.

Berdasarkan Tabel 1 dapat dijelaskan bahwa terjadi peningkatan berat pada perlakuan sejalan dengan meningkatnya lama pemeliharaan. Terlihat bahwa pada perlakuan rumput laut hasil kultur jaringan setelah 30 hari pemeliharaan terdapat peningkatan bobot sebesar $343 \%$ dengan laju pertumbuhan harian (DGR) sebesar $4,97 \%$ sementara untuk bibit lokal dijumpai peningkatan bobot dan laju pertumbuhan harian (DGR) sebesar 230\%dan 3,97\% Laju pertumbuhan harian lebih besar dijumpai pada 15 hari pertama pemeliharaan daripada 15 hari pemeliharaan berikutnya dengan DGR untuk 15 hari pemeliharaan pertama dan 15 hari pemeliharaan berikutnya adalah 5,33\%dan 4,60\%untuk bibit kultur jaringan dan 5,06\%dan 2,87\%untuk bibit lokal, secara berturut-turut. Hasil uji Anova, DGR bibit kultur jaringan dan bibit lokal setelah 30 hari pemeliharaan menunjukkan perbedaan yang nyata $(P<0,05)$.

Dibandingkan dengan metode rawai, laju pertumbuhan harian bibit hasil kultur jaringan $(6,70 \%)$ dengan sumber bibit yang sama (Rosmiati, 2017) dengan metode sebar dalam hapa di tambak adalah lebih rendah. Proses penambahan berat bibit rumput laut dengan metode tebar lebih rendah karena kurangnya intensitas cahaya yang diterima dan kurang baiknya pergerakan air yang terlihat pada thallus bibit rumput laut yang tertutup oleh lumpur sehingga memengaruhi pertumbuhan bibit. Menurut Mamang \& Nurfadly (2008), pergerakan air yang baik dapat menghindarkan akumulasi silt dan organisme epifit yang menempel pada thallus yang dapat menghalangi pertumbuhan rumput laut.

Bibit rumput laut hasil kultur jaringan yang dipelihara di tambak Kabupaten Sinjai dapat tumbuh lebih baik dibandingkan bibit yang sama dipelihara di Kabupaten Brebes (SGR 1,41\%) (Trawanda et al., 2014). Ini diduga disebabkan karena sumber bibit yang digunakan untuk kultur jaringan memang bersumber dari bibit lokal Kabupaten Sinjai sehingga setelah dikultur jaringan secara vegetatif dengan penambahan pupuk dan dikembalikan di lokasi yang sama bibit hasil kultur jaringan sudah mampu beradaptasi dengan kondisi perairan tambak Kabupaten Sinjai.
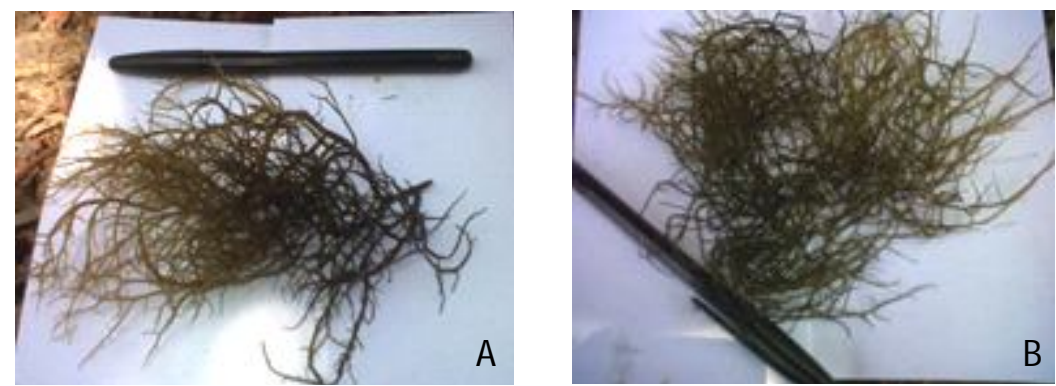

Gambar 1. Morfologi bibit rumput laut G. verrucosa hasil kultur jaringan (A), dan lokal Sinjai (B).

Figure 1. Morphology of seaweed seed $\mathbf{G}$. verrucosa from tissue-cultured (A) and Sinjai locality (B). 
Tabel 1. Rata-rata berat bibit rumput laut $\mathrm{G}$. verucosa $(\mathrm{kg})$ yang dipelihara di tambak dengan lama pemeliharaan 0,15 , dan 30 hari

Table 1. The average weight of seaweed seed $\mathbf{G}$. verucosa $(\mathrm{kg})$ cultivated in pond for 0,15 , and 30 days of rearing

\begin{tabular}{cccc}
\hline \multirow{2}{*}{$\begin{array}{c}\text { Perlakuan } \\
\text { Treatments }\end{array}$} & \multicolumn{3}{c}{$\begin{array}{c}\text { Berat pada masa pem eliharaan } \\
\text { Weight at the rearing time } \mathbf{( k g )}\end{array}$} \\
\cline { 2 - 4 } & 0 hari (day) & $\mathbf{1 5}$ hari (days) & $\mathbf{3 0}$ hari (days) \\
\hline A & 10.0 & $22.2 \pm 2.75$ & $44.3 \pm 4.16$ \\
B & 10.0 & $21.4 \pm 3.35$ & $33.0 \pm 4.35$ \\
\hline
\end{tabular}

Keterangan: Bibit hasil kultur jaringan (A) dan lokal (B)

Note: $\quad$ Seed from tissue culture $(A)$ and local (B)

Pertumbuhan bibit rumput laut baik bibit hasil kultur jaringan maupun bibit lokal berada pada kategori baik karena keduanya memperlihatkan SGR di atas 2\%per hari (Sulistijo, 2002). Apabila mengacu pada Mubarak (1990) bibit rumput laut hasil kultur jaringan menunjukkan pertumbuhan yang sudah menguntungkan karena SGR-nya sudah lebih dari 3\%

\section{Kandungan Agar}

Kandungan agar pada rumput laut Gracilaria verucosa sangat dipengaruhi oleh lingkungan tempat bertumbuh, serta variasi musim pada dibudidaya. Bibit rumput laut hasil kultur jaringan menggunakan indukan dari hasil seleksi yang tentunya memiliki keunggulan antara lain memiliki pertumbuhan yang lebih baik, serta kondisi rumput laut yang bebas dari cemaran penyakit dan parasit, sehingga pada pembesaran dan budidaya rumput laut di lapangan yang disandingkan dengan bibit lokal memperlihatkan perbedaan pada thallus, serta yield agar yang dihasilkan.

Hasil pengujian kandungan agar rumput laut Gracilaria verucosa pada awal dan akhir penelitian ditunjukkan pada Gambar 2.
Rata-rata kandungan agar bibit yang dperoleh setelah 30 hari pemeliharaan adalah 22,19 $\pm 2,45 \%$ (kultur jaringan) dan 16,50 $\pm 0,96 \%$ (lokal). Gambar 2 menunjukkan bahwa hasil uji rendamen terlihat bahwa kandungan agar bibit rumput laut hasil kultur jaringan pada awal dan akhir penelitian adalah lebih tinggi daripada bibit rumput laut lokal Sinjai. Setelah 30 hari pemeliharaan, bibit rumput laut hasil kultur jaringan memperlihatkan adanya peningkatan rendemen agar sebesar $21,39 \%$ sementara bibit rumput laut lokal menunjukkan adanya peningkatan yang jauh lebih rendah yaitu $1,41 \%$ Hasil uji Anova menunjukkan bahwa kandungan agar bibit kultur jaringan dan bibit lokal menunjukkan perbedaan yang nyata $(P<0,05)$.

Persentase kandungan agar yang diperoleh lebih rendah jika dibandingkan dengan persentase kandungan agar bibit rumput laut hasil kultur jaringan yang dibudidaya dengan bibit yang sama dengan metode budidaya rawai (long line method) dengan kandungan agar sebesar 25\%(Rosmiati et al., 2017). Hal ini sesuai dengan pernyataan (Widiastuti, 2011) bahwa perbedaan metode penanaman bibit akan menghasilkan jumlah dan kandungan agar yang berbeda.

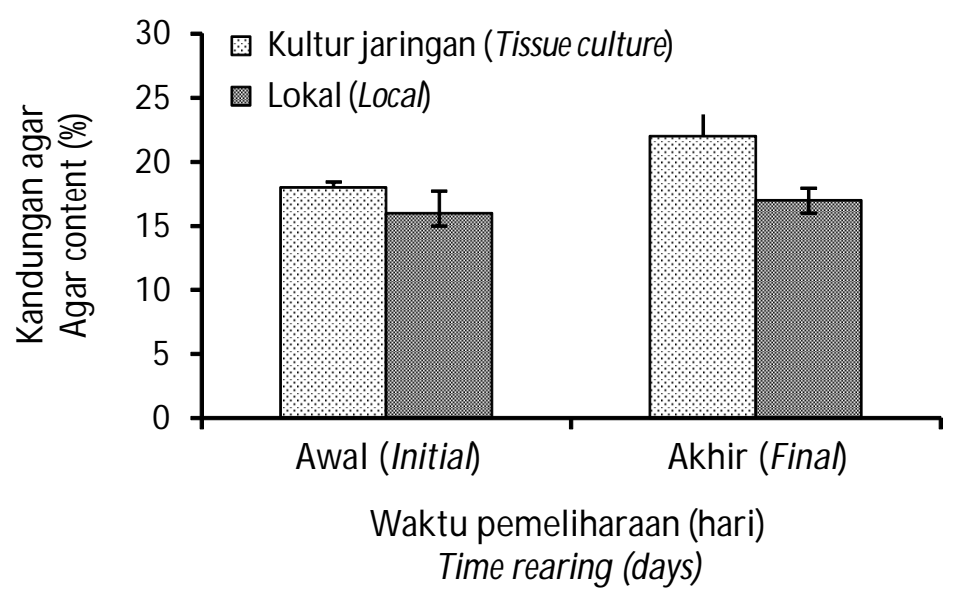

Gambar 2. Kandungan agar rumput laut Gracilaria verucosa pada awal dan akhir percobaan.

Figure 2. Agar content of Gracilaria verucosa at the initial and at the end of experiment. 
Tabel 2. Kandungan agar rumput laut Gracilaria verrucosa setelah 30 hari pemeliharaan

Table 2. Agarose content of Gracilaria verucosa after 30 days of rearing

\begin{tabular}{ccc}
\hline $\begin{array}{c}\text { Perlakuan } \\
\text { Treatments }\end{array}$ & $\begin{array}{c}\text { Agar }(\% \pm \text { SD (awal) } \\
\text { Agarose }(\% \pm \text { SD (initial) }\end{array}$ & $\begin{array}{c}\text { Agar }(\% \pm \text { SD (akhir) } \\
\text { Agarose }(\%) \pm \text { SD (final) }\end{array}$ \\
\hline A & $18.28 \pm 0.42$ & $22.19 \pm 2.45$ \\
B & $16.27 \pm 1.73$ & $16.50 \pm 0.96$ \\
\hline
\end{tabular}

Penanaman bibit dengan metode sebar akan langsung jatuh ke dasar tambak yang berlumpur sehingga berpengaruh terhadap kualitas rumput laut (kandungan agar).

Selain metode, kandungan agar rumput laut juga dipengaruhi oleh jenis rumput laut, iklim, metode ekstraksi, waktu pemanenan, umur tanaman, lingkungan, dan lokasi budidaya (Santika et al., 2014; Azizah et al., 2018). Oleh karena itu, besarnya rendemen ini belum tentu sama untuk rumput laut yang sama apabila dipanen pada waktu yang berbeda maupun ditanam padalokasi yang berbeda. Kandungan agar rata-rata yang diperoleh selama penelitian tergolong memiliki kualitas rendemen yang tinggi di atas rata-rata rendemen agar yang umumnya terkandung pada Gracilaria verucosa yaitu $8 \% 14 \%$ (Poncomulyo et al., 2008). Kandungan agar yang diperoleh dari hasil penelitian ini juga masih lebih tinggi dibandingkan dengan hasil yang diperoleh oleh Basith et al. (2014) yaitu 3,71\%dengan menggunakan bibit kultur jaringan dan metode yang sama dan tidak berbeda jauh dengan rendemen agar yang diperoleh di tambak Lampung yaitu 20,21\% (Subaryono \& Murdinah, 2011).

\section{Kekuatan Gel (Gel Strength)}

Nilai rata-rata gel strength yang dihasilkan pada penelitian ini adalah $204,20 \pm 0,45 \mathrm{~g} / \mathrm{cm}^{2}$ pada perlakuan bibit kultur jaringan lebih tinggi $59,41 \%$ daripada perlakuan bibit lokal $128,10 \pm 1,55 \mathrm{~g} / \mathrm{cm}^{2}$ (Gambar 3). Hasil uji Anova gel strength bibit kultur jaringan dan bibit lokal menunjukkan perbedaan yang nyata $(P<0,05)$. Hal ini disebabkan karena kandungan agar yang dihasilkan juga berbeda nyata. Gel strength hasil penelitian ini lebih tinggi dari gel strength bibit rumput laut hasil kultur jaringan yang dipelihara di tambak Kabupaten Brebes $\left(129,279 \mathrm{~g} / \mathrm{cm}^{2}\right)$.

Gel strength hasil penelitian ini juga jauh lebih tinggi dari gel strength bibit rumput laut yang dilaporkan oleh Suryaningrum et al. (1994) pada spesies yang sama yaitu sebesar 34,67 sampai $97,33 \mathrm{~g} / \mathrm{cm}^{2}$ tetapi lebih rendah apabila dibandingkan dengan yang dilaporkan oleh Utomo (1996) dengan gel strength sebesar $355 \mathrm{~g} /$ $\mathrm{cm}^{2}$ dengan menggunakan metode perlakuan alkali. Apabila mengacu pada standar kualitas agar-agar di Jepang gel strength agar-agar yang diperoleh pada pada penelitian ini masih berada pada kategori mutu tiga yaitu gel strength lebih besar dari $150 \mathrm{~g} / \mathrm{cm}^{2}$ (Suryaningrum et al., 1994).

Rendahnya nilai gel strength agar yang diisolasi dari bibit hasil kultur jaringan pada penelitian ini dikarenakan usia bibit yang masih terlalu muda. Menurut Suryaningrum (1988), jika rumput laut dipanen masih terlalu muda maka kandungan asam sulfatnya lebih tinggi. Kandungan sulfat berpengaruh terhadap kekuatan gel dari agar-agar, semakin tinggi kandungan ester sulfat dalam agar-agar, maka kekuatan gel yang terbentuk akan semakin rendah (Chapman \& Chapman, 1980).

\section{Kualitas Air}

\section{Suhu}

Kisaran suhu pada lokasi tambak selama penelitian adalah antara $27^{\circ} \mathrm{C}-32^{\circ} \mathrm{C}$. Ini menunjukkan bahwa kondisi suhu masih berada pada kisaran yang memungkinkan untuk $\mathrm{G}$. verrucosa untuk berkembang dan tumbuh dengan baik. Hal ini sesuai pernyataan Amalia (2013) yang melaporkan bahwa rumput laut dapat tumbuh dengan baik pada perairan dengan kisaran suhu $20^{\circ} \mathrm{C}-33^{\circ} \mathrm{C}$. Peningkatan suhu pada tambak terjadi pada siang hari dan menurun pada sore hari sehingga suhu yang teramati berfluktuasi. Peningkatan suhu sampai $32^{\circ} \mathrm{C}$ yang diamati dikarenakan pada bulan Juli sudah mulai musim panas sehingga berdampak pada DGR bibit mulai menurun pada 15 hari periode pemeliharaan berikutnya.

\section{Salinitas}

Selama masa pemeliharaan rumput laut di lokasi penelitian yang diukur pada pagi dan so re hari berkisar antara 28-30 ppt. Kisaran salinitas yang terukur tersebut masih berada pada kisaran yang masih dapat ditolerir untuk pertumbuhan G. verrucosa. Anggadiredja et al. (2006) melaporkan bahwa kisaran salinitas yang baik untuk pertumbuhan rumput laut adalah 28-33 ppt. 


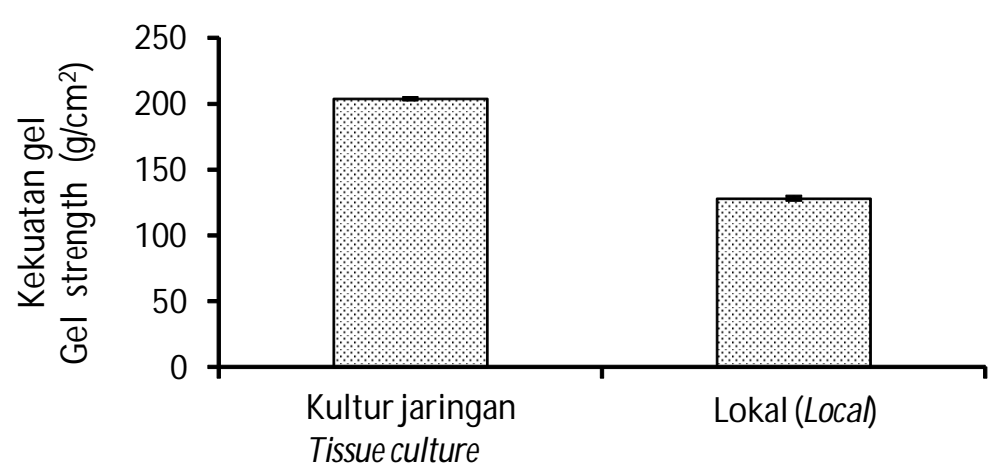

Sumber bibit (Source of seeds)

Gambar 3. Rata-rata ( \pm SD) gel strength bibit rumput laut setelah 30 hari siklus pemeliharaan.

Figure 3. Mean ( \pm SD) of seaweed seed gel strength at 30 days of rearing.

\section{Nitrat}

Nitrat yang diperoleh selama penelitian adalah 0,108-0,810 mg/L. Ini menunjukkan bahwa kondisi perairan terutama nitrat cukup optimal mendukung pertumbuhan rumput laut. Menurut Armita (2011), batas toleransi nitrat terendah untuk pertumbuhan alga adalah $0,1 \mathrm{mg} / \mathrm{L}$ sedangkan batas tertingginya adalah $3 \mathrm{mg} / \mathrm{L}$.

\section{Fosfat}

Kandungan fosfat yang diamati pada penelitian ini adalah 0,0893-1,100 mg/L. Menurut Sadarang \& Thana (1995), melaporkan bahwa perairan dikatakan subur apabila kadar fosfatnya berkisar antara 0,0600-10,0000 $\mathrm{mg} / \mathrm{L}$. Berkurangnya kandungan fosfat di perairan diduga karena telah dimanfaatkan oleh rumput laut sebagai unsur hara esensial yang yang berperan pada proses fotosintesis.

\section{KESIMPULAN}

Penanaman rumput laut Gracilaria verucosa hasil kultur jaringan dengan metode sebar (broadcast) di tambak Kabupaten Sinjai terlihat memiliki laju pertumbuhan, kandungan agar dan gel strength sebesar 4,97\% 22,19 \pm 2,45\%dan 04,20 $\pm 0,45 \mathrm{~g} / \mathrm{cm}^{3}$ lebih tinggi dibandingkan bibit lokal dengan laju pertumbuhan, kandungan agar dan gel strength sebesar $3,90 \% 16,50 \pm 0,96 \%$ dan $128,10 \pm 1,55 \mathrm{~g} / \mathrm{cm}^{3}$.

\section{UCAPAN TERIMA KASIH}

Penulis mengucapkan terima kasih kepada Kementerian Kelautan dan Perikanan yang telah membiayai sebagian daripada penelitian ini melalui
APBN tahun 2014, serta kelompok tani Kabupaten Sinjai yang telah memberikan fasilitas dalam melaksanakan penelitian ini.

\section{DAFTAR ACUAN}

Amalia, D.R.N. (2013). Efek temperatur terhadap pertumbuhan Gracilaria verrucosa. Skripsi. Universitas Jember. Jember.

Amir, A. (2018). Kemarau panen rumput laut melimpah namun harga anjlok. https://regional.kompas.com/ read/2018/09/24/12272771/kemarau-panen-rumputlaut-melimpah-namun-harga-anjlok, Diakses 3 Mei 2019.

Anggadiredja, J.T., Irawati, S., \& Kusmiyati. (2006). Rumput Laut: Pembudidayaan, Pengolahan, dan Pemasaran Komoditas Perikanan Potensial. Penerbit Penebar Swadaya, Jakarta.

Anggadiredja, J.T., Zatnika, A., Purwoto, H., \& Istini, S. (2010). Rumput laut. Jakarta: Penebar Swadaya.

Armita, D. (2011). Analisis perbandingan kualitas air di daerah budidaya rumput laut dengan daerah tidak ada budidaya rumput laut, di Dusun Malelaya Desa Punaga Kecamatan Mangarabombang Kabupaten Takalar. Skripsi. Universitas Hasanuddin. Makassar.

Azizah, M.N., Rahman, A., \& Balubi, A.M. (2018). Pengaruh jarak tanam bibit yang berbeda terhadap kandungan agar rumput laut (Gracilaria) menggunakan metode longline di tambak. Media Akuatika, 3(1), 556-563.

Basith, A.T., Rejeki, S., \& Ariyati, R.W. (2014). Pengaruh cara perolehan bibit hasil seleksi, nonseleksi, dan kultur jaringan terhadap pertumbuhan, kandungan agar, dan gel strength rumput laut 
G. verrucosa yang dibudidayakan dengan metode broadcast di tambak. Jurnal Manajemen Budidaya dan Tekhnologi, 3(2), 18-24.

Chapman, V.J. \& Chapman, D.J. (1980). Seaweed and their uses. London: Chapman and Hall, 333 pp.

DKP Sinjai. (2014). Statistik kelautan dan perikanan Kabupaten Sinjai Tahun 2014. Dinas Kelautan dan Perikanan Kabupaten Sinjai.

Mamang \& Nurfadly. (2008). Laju pertumbuhan bibit rumput laut Eucheuma cottonii dengan perlakuan asal thallus terhadap bobot bibit di perairan Lakeba, Kota Bau-Bau, Sulawesi Tenggara. Skripsi. Institut Pertanian Bogor. Bogor.

Mubarak, H. (1990). Petunjuk teknis budidaya rumput laut. Jakarta: Pusat Penelitian dan Pengembangan Perikanan, $32 \mathrm{hlm}$.

Mulyaningrum, S.R.H., Parenrengi, A., \& Suryati, E. (2015). Pertumbuhan dan Perkembangan eksplan rumput laut Gracilaria verrucosa dan Gracilaria gigas pada aklimatisasi di tambak. Ilmu Kelautan, 20(3), 135-142.

Parenrengi, A., Suryati, E., \& Rahmansyah. (2011). Budidaya rumput laut. Badan Penelitian dan Pengembangan Kelautan dan Perikanan, Kementrian Kelautan dan Perikanan Republik Indonesia, Jakarta.

Poncomulyo, T., Maryani, H., \& Kristiana, L. (2008). Budidaya dan pengolahan rumput laut. Jakarta: PT Agromedia Pustaka. $136 \mathrm{hlm}$.

Rosmiati. (2017). Analisis pertumbuhan dan perbanyakan bibit Gracilaria sp. hasil kultur jaringan di tambak Kabupaten Sinjai. Prosiding Simposium Nasional Kelautan dan Perikanan IV. Universitas Hasanuddin. Makassar, 19 Mei 2017, hlm. 390-396.

Sulistijo, M.S. (2002). Perkembangan budidaya rumput laut di Indonesia. Jakarta: Puslitbang Oceanografi LIPI, $61 \mathrm{hlm}$.

Subandiyono, \& Hastuti, S. (2014). Beronang serta prospek budidaya laut di Indonesia. Semarang: UPT Undip Press, $78 \mathrm{hlm}$.
Santika, L.G., Widodo, F., \& Romadhon. (2014). Karakteristik agar rumput laut Gracilaria verucosa budidaya tambak dengan perlakuan konsentrasi alkali pada umur panen yang berbeda. Jurnal Pengolahan dan Bioteknologi Hasil Perikanan, 3(4), 98-105.

Sadarang, A., \& Thana, D. (1995). Studi kualitas fisikakimia dan biologi estuari Sungai Teko yang mendapat limbah pabrik gula arasoe bone untuk pengembangan budidaya pantai. Pusat Studi Lingkungan (PS- L)-Lembaga Penelitian, Universitas Hasanuddin. Ujung Pandang.

Subaryono, \& Murdinah. (2011). Kualitas agar- agar dari rumput laut Gracilaria chilensis yang dibudidayakan di Lampung. Prosiding Forum Inovasi Teknologi Akuakultur, (2), 1153-1158.

Suryaningrum, T.D., Murtini, J.T., Wibowo, S., \& Suherman, M. (1994). Kajian sifat fisik dan organoleptik tepung agar-agar dari rumput laut Gracilaria tambak. Jurnal Pasca Panen Perikanan, 83, 1-12.

Suryaningrum, T.D. (1988). Kajian Sifat-sifat Mutu Komoditi Rumput Laut Budidaya Jenis Euchema cottonii dan Euchema spinosum. Tesis. Fakultas Pasca Sarjana, IPB. Bogor.

Trawanda, S.A., Sri Rejeki, \& Ariyati, R.W. (2014). Kuantitas dan kualitas rumput laut Gracilaria sp. bibit hasil seleksi dan kultur jaringan dengan budidaya metode long line di tambak. Journal of Aquaculture Management and Technology, 3(2), 150-158.

Utomo, B.S.B. (1996). Extraction and properties of agar from Gracilaria verrucosa and Gelidiella acerosa harvested in Indonesia. Ph.D. Thesis. Faculty of Applied Science. Dept. of Food Science and Technology. The University of New South Wales. Australia, $415 \mathrm{pp}$.

Widiastuti, I.M. (2011). Produksi G. verrucosa yang dibudidayakan di tambak dengan berat bibit dan jarak tanam yang berbeda. Jurnal Agrisains, 12(1), 57-62. 